\title{
50th Anniversary of the EAGEN
}

Successes and Failures in Gastroenterology during the Past 50 Years

with an Outlook to the Future

Editors

Peter Malfertheiner, Munich

Guenter J. Krejs, Graz

Antonio Gasbarrini, Rome

5 figures, 5 in color, and 15 tables, 2020 
S. Karger

Medical and Scientific Publishers

Basel $\cdot$ Freiburg $\cdot$ Hartford $\cdot$ Oxford

Bangkok $\cdot$ Dubai $\cdot$ Kuala Lumpur .

Melbourne $\cdot$ Mexico City .

Moscow $\cdot$ New Delhi $\cdot$ Paris ·

Shanghai $\cdot$ Tokyo
Disclaimer

The statements, opinions and data contained in this publication are solely those of the individual authors and contributors and not of the publisher and the editor(s). The appearance of advertisements in the journal is not a warranty, endorsement, or approval of the products or services advertised or of their effectiveness, quality or safety. The publisher and the editor(s) disclaim responsibility for any injury to persons or property resulting from any ideas, methods, instructions or products referred to in the content or advertisements.

Drug Dosage

The authors and the publisher have exerted every effort to ensure that drug selection and dosage set forth in this text are in accord with current recommendations and practice at the time of publication. However, in view of ongoing research, changes in government regulations, and the constant flow of information relating to drug therapy and drug reactions, the reader is urged to check the package insert for each drug for any change in indications and dosage and for added warnings and precautions. This is particularly important when the recommended agent is a new and/or infrequently employed drug.
All rights reserved.

No part of this publication may be translated into other languages, reproduced or utilized in any form or by any means, electronic or mechanical, including photocopying, recording microcopying, or by any information storage and retrieval system, without permission in writing from the publisher or in the case of photocopying, direct payment of a specified fee to the Copyright Clearance Center (see "General Information")

(c) Copyright $2019 / 2020$ by S. Karger AG,

P.O. Box, CH-4009 Basel (Switzerland)

Printed on acid-free and non-aging paper (ISO 9706)

ISBN 978-3-318-06700-2

e-ISBN 978-3-318-06701-9

\section{KARGER}




\title{
Contents
}

\author{
Preface
}

93 50th Anniversary of the EAGEN

Malfertheiner, P. (Munich); Krejs, G.J. (Graz)

Review Articles

94 EAGEN and UEG: A Long-Term Partnership with a Focus on Education Hammer, H.F. (Graz)

97 Why the $\mathbf{N}$ (Nutrition) was Added in the EAGEN Acronym? Milosavljević, T.; Kostić-Milosavljević, M. (Belgrade)

100 How to Prepare Educational Lecture: EAGEN 50 Years of Experience Regula, J. (Warsaw)

104 Pharmacological Approach to Gastric Acid Suppression: Past, Present, and Future

Herszényi, L.; Bakucz, T.; Barabás, L.; Tulassay, Z. (Budapest)

112 Peptic Ulcer: Chapter Closed?

Malfertheiner, P. (Munich/Magdeburg); Schulz, C. (Munich)

117 Microscopic Colitis: A Challenging Disorder

Tulassay, Z.; Mihaly, E.; Herszényi, L. (Budapest)

122 Irritable Bowel Syndrome Subtypes: New Names for Old Medical Conditions Grad, S.; Dumitrascu, D.L. (Cluj-Napoca)

128 From Regular Catharsis with Castor Oil to Recognizing the Importance of the Intestinal Microbiota

Settanni, C.R.; Ianiro, G.; Franceschi, F.; Gasbarrini, G.; Gasbarrini, A. (Rome)

137 Evolution and Revolution of Hepatitis C Management: From Non-A, Non-B Hepatitis Toward Global Elimination

Basyte-Bacevice, V.; Kupcinskas, J. (Kaunas)

143 Nonalcoholic Fatty Pancreas Disease: Clinical Consequences

Dite, P. (Brno/Ostrava); Blaho, M.; Bojkova, M. (Ostrava); Jabandziev, P.; Kunovsky, L. (Brno)

150 Endoscopic Treatment of Obesity: From Past to Future

Štimac, D.; Klobučar Majanović, S.; Belančić, A. (Rijeka)

163 Author Index

164 Subject Index 